\section{Effect of Oil-in-Water Emulsions on 5-Aminolevulinic Acid Uptake and Metabolism to PpIX in Cultured MCF-7 Cells}

\author{
Hanne Mørck Nielsen, ${ }^{1,2,5}$ Caroline Aemisegger, ${ }^{1}$ \\ Gerd Burmeister, ${ }^{3}$ Ursula Schuchter, ${ }^{4}$ and \\ Bruno Gander ${ }^{1}$
}

Received April 6, 2004; accepted July 29, 2004

Purpose. To identify the optimal vehicle for fast and efficient cellular production of the photosensitizer, protoporphyrin IX (PpIX), upon administration of 5-aminolevulinic acid (ALA).

Methods. ALA in various oil/water o/w emulsions was applied to the human mammary epithelial cell line (MCF-7) cultured in microplates. Upon incubation for 1-4 h, the accumulated amount of PpIX was determined by fluorescence spectroscopy. Variables such as the $\mathrm{pH}$ and concentration of the emulsions, the temperature and duration of incubation were examined along with the importance of ALA concentration and the presence of endocytosis inhibitors.

Results. An increase in the amount of produced PpIX was observed with an increase in extracellular $\mathrm{pH}$, incubation temperature, and ALA concentration. A saturable mechanism of PpIX accumulation was evident, mainly as a result of the uptake mechanism for ALA. Some of the o/w emulsions increased the amount of intracellular PpIX, and the results indicated that this was not due to an increased $\mathrm{k}_{\mathrm{m}}$ of the extracellular ALA to intracellular PpIX conversion, but to the increased endocytotic uptake in the presence of the emulsions. In general, the increase in PpIX in the presence of emulsions relative to the control was more pronounced after $1 \mathrm{~h}$ as compared to after $2-4 \mathrm{~h}$.

Conclusions. The formation of PpIX in MCF-7 cells exposed to ALA is improved by the presence of certain $\mathrm{o} / \mathrm{w}$ emulsions, which could be explained by endocytosis.

KEY WORDS: aminolevulinic acid uptake; endocytosis; MCF-7 cells; oil-in-water emulsions; photodynamic diagnosis and therapy; protoporphyrin IX.

\section{INTRODUCTION}

Photodynamic diagnosis and therapy is a noninvasive technique well suited for light-accessible superficial neoplastic cells (1). A range of studies have shown that topically applied 5-aminolevulinic acid (ALA) - a heme precursor-in photodynamic diagnosis and therapy of oncologic (2) and non-oncologic pathologies (3) is superior to conventional treatments. Under physiologic conditions, the synthesis of

\footnotetext{
${ }^{1}$ Institute of Pharmaceutical Sciences, Swiss Federal Institute of Technology Zürich (ETH Zürich), Winterthurerstrasse 190, 8057 Zürich, Switzerland.

${ }^{2}$ Department of Pharmaceutics, The Danish University of Pharmaceutical Sciences, 2 Universitetsparken, 2100 Copenhagen, Denmark.

${ }^{3}$ ASAT AG, 77 Baarerstrasse, 6302 Zug, Switzerland.

${ }^{4}$ Division of Gynecology, University Hospital Zürich, 100 Rämistrasse, 8091 Zürich, Switzerland.

${ }^{5}$ To whom correspondence should be addressed. (e-mail: hmn@ dfuni.dk)
}

ALA from glycine and succinyl CoA is inhibited by a negative feedback mechanism caused by heme, but if exogenous ALA is introduced, the amount of the metabolite protoporphyrin IX (PpIX) increases $(1,2)$. PpIX induces apoptosis, is the main endogenous photosensitizer derived from ALA, and it tends to accumulate more easily in tumor tissue compared to normal tissue. The reason for this is not precisely known, but probably depends on a variety of factors, such as an increased uptake or increased affinity of ALA caused by the neoplastic cells, a faster metabolism to PpIX due to slightly higher temperatures in tumor cells as compared to normal cells, or a decreased transformation of PpIX to heme $(1,2)$.

The main clinical limitations with ALA are its instability at physiologic $\mathrm{pH}$ as well as its hydrophilicity, which result in relatively low cellular uptake. ALA is relatively stable at lower $\mathrm{pH}$ values $(4,5)$, as dimerization-and further formation of metabolites-depends on the amount of anionic ALA. The $\mathrm{pK}_{\mathrm{a}}$ values of ALA in an aqueous solution are approximately 4 and 8 (5); thus, at $\mathrm{pH}$ values below 4, ALA is quite stable. Other parameters, which strongly influence ALA stability, encompass the ALA concentration in a formulation, as well as the viscosity and storage temperature of the formulation (6). Approaches taken to increase the cellular uptake have mainly dealt with increasing the passive diffusion of ALA across the plasma membrane by using more lipophilic ALA prodrugs $(7,8)$. Especially ALA-methylester was effective in a range of clinical trials (1). When using ALAhexylester, PpIX formation was 2.5-3.5 times higher for up to $24 \mathrm{~h}$ of incubation in cell cultures (8). In vivo, the increase was, however, merely 1.3 (8) and in organ cultures, PpIX formation was not increased with the hexylester (7). Another approach is to target ALA to the mitochondria by increasing the affinity for the mitochondrial membrane, which might be achieved by the use of specific lipids in the formulation (9). Topical application of ALA in formulations with increased ALA stability and/or permeability has been investigated using gels (10) and films (11). Furthermore, encapsulation of ALA in nanoparticles and application as colloidal lotion was highly effective, probably due to increased chemical stability of ALA (12). Water-in-oil and oil-in-water formulations have been used in clinical studies, all with therapeutic success (13), which probably is due to increased stability of ALA as well as improved permeability of ALA across the biological barrier. However, a more recent study showed that the accumulation of ALA in a murine subcutaneous adenocarcinoma in vivo model was higher when applied topically in saline (with or without DMSO) as compared to a w/o-based cream, vaseline or liposomes (14). Furthermore, incorporation of ALA into liposomes did not increase the rate of PpIX synthesis, neither in tissue explant culture nor in the M2 mammary adenocarcinoma cell line (7).

An increased active uptake of ALA could improve its therapeutic effect. ALA is recognized as a substrate by several membrane transporters. For example, PEPT2 translocates ${ }^{3} \mathrm{H}$-ALA by means of a saturable transport mechanism (15). The authors of that study concluded that for neutral compounds, such as ALA, extracellular $\mathrm{pH}$ only alters the maximal transport rate, but not the affinity to the transporter (15). The PEPT2 transporter seems to be expressed in mammary gland epithelium (16), and RT-PCR screening of rabbit 
mammary gland also showed the presence of mRNA for the PEPT2 transporter (15). Recently, PEPT1 was found to transport ALA into epithelial cells of the extrahepatic biliary duct with an apparent affinity constant of $2.1 \mathrm{mM}$ (17). In intestinal Caco-2 cells, mainly the PEPT1 and the basolateral peptide transporter with the $\mathrm{k}_{\mathrm{m}}$ values of 1.6 and $2.4 \mathrm{mM}$, respectively, translocated ALA (18), and the uptake of ALA was only slightly inhibited by GABA. On the contrary, in a murine mammary adenocarcinoma cell line, the uptake of ALA was mediated by a BETA transporter, as inhibition was seen with GABA and not with substrates for the PEPT1 and PEPT2 transporters (19); here, the ALA efflux was diffusion controlled (20). Also in a human colonic adenocarcinoma cell line, ALA was found to be a substrate for the BETA transporter (21).

Because an increased uptake of ALA may both reduce the amount of drug to be applied as well as shorten the time of incubation before diagnosis or therapy, the objective of the present study was to optimize uptake and/or metabolism of ALA in MCF-7 cells, that is, to assess the overall kinetics of PpIX formation. The MCF-7 cell line is derived from pleural effusion from a metastatic breast carcinoma. The cells are of human origin and presumed to conserve some differentiated mammary epithelial cell function (22), that is, potentially the PEPT2 transporter. MCF-7 cells have previously been used in studies with photosensitizers (23). In particular, the effect which different oil/water $(\mathrm{o} / \mathrm{w})$ emulsions have on the amount of PpIX formed was evaluated. Different endocytosis inhibitors were investigated to assess mechanistic features associated with the $\mathrm{o} / \mathrm{w}$ formulations.

\section{MATERIALS AND METHODS}

\section{Materials}

The MCF-7 cells (no. HTB-22) were from ATCC. Fetal bovine serum (FBS) was from BioChrom (Berlin, Germany), whereas Optimem 1, penicillin/streptomycin, trypsin-EDTA, phosphate-buffered saline free of $\mathrm{MgCl}_{2}$ and $\mathrm{CaCl}_{2}$ (PBS), RPMI 1640 with L-glutamine but without phenol red (RPMI), and Hanks balanced salt solution (HBSS) were from Gibco (Paisley, UK). 96-well Optilux black with transparent polystyrene bottom (Falcon, Becton Dickinson Labware, Franklin Lakes, NJ, USA) were used for the uptake experiments and transparent polystyrene 96-well plates (TPP, Trasadingen, Switzerland) were used for the dehydrogenase activity assays.

5-Aminolevulinic acid $\mathrm{HCl}$ (ALA) was synthesized by Sochinaz (Vionnaz, Switzerland) and kindly provided by ASAT (Zug, Switzerland). Intralipid 10\% (IL10) and Lipovenös 20\% (LV20) were from Fresenius Kabi (Stans, Switzerland). Squalene, glycerol and L- $\alpha$-phosphatidyl-L-serin sodium salt were from Fluka (Buchs, Switzerland), Synperonic F68 from ICI (Middlesborough, UK), Lipoid E PC from Lipoid (Ludwigshafen, Germany), and phosphatidylglycerol (1,2-dipalmitoyl-sn-glycero-3-phosphoglycerol sodium salt) from Sygena (Liestal, Switzerland). Ammonium chloride $\left(\mathrm{NH}_{4} \mathrm{Cl}\right)$, D-mannitol, monensin sodium salt, brefeldin A, cytochalasin D, and Triton X-100 were from Fluka (Buchs, Switzerland). Protein assay kit [bicinchoninic acid (BCA) solution and $\left.4 \% \mathrm{CuSO}_{4}\left(\mathrm{H}_{2} \mathrm{O}\right)_{5}\right]$ and phenazine methosulfate (PMS) were purchased from Sigma-Aldrich (St. Louis, MO, USA), and CellTiter 96 AQueous MTS Reagent Powder was from Promega (Madison, WI, USA).

\section{Preparation of O/W Emulsions}

The emulsifiers, glycerol and water were mixed and stirred magnetically until dissolution, which took a few minutes at room temperature for the mixture with Synperonic $\mathrm{F} 68$, and $1 \mathrm{~h}$ at $50^{\circ} \mathrm{C}$ for the mixtures containing the phosphatidyl compounds (Table I). The oil phase was then added and the mixtures emulsified by high-speed mixing at $5000 \mathrm{rpm}$ for $10 \mathrm{~min}$ at $50^{\circ} \mathrm{C}$ (Polytron, Kinematica, Littau-Lucerne, Switzerland). Then, the emulsions were homogenized through 5 passages in a Microfluidizer (M-110T, Microfluidics, Newton, MA, USA). The obtained nanoemulsions (Table I) were stored at $4^{\circ} \mathrm{C}$ until further use.

The droplet size, measured by laser light diffraction (Zetasizer 3, Malvern Instruments, Worchester, UK), was in the range of 350-400 $\mathrm{nm}$ for the commercial emulsions and for SOPG(0.6), SOPG(0.2) and SOPS(0.2), while it was in the range of $220-240 \mathrm{~nm}$ for SQF68. The zeta potential of the $\mathrm{O}$-droplets was measured in triplicate by electrophoretic mo-

Table I. Composition of the O/W-Emulsions

\begin{tabular}{|c|c|c|c|c|c|c|}
\hline Component & IL10 & LV20 & SQF68 & SOPG (0.6) & SOPG (0.2) & SOPS $(0.2)$ \\
\hline Quantity (\%) & $(\mathrm{w} / \mathrm{v})$ & $(\mathrm{w} / \mathrm{v})$ & $(w / w)$ & $(w / w)$ & $(w / w)$ & $(w / w)$ \\
\hline Soya oil & 10.0 & 20.0 & & 10.0 & 10.0 & 10.0 \\
\hline Squalene & & & 10.0 & & & \\
\hline Synperonic F68 & & & 1.2 & & & \\
\hline Egg lecithin & 1.2 & $1.2^{a}$ & & $0.6^{b}$ & $1.0^{b}$ & $1.0^{b}$ \\
\hline Phosphatidylserine & & & & & & 0.2 \\
\hline Phosphatidylglycerol & & & & 0.6 & 0.2 & \\
\hline Glycerine $98 \%$ & 2.2 & & 2.2 & 2.2 & 2.2 & 2.2 \\
\hline Water & 86.6 & 78.8 & 86.6 & 86.6 & 86.6 & 86.6 \\
\hline Zeta potential $(\mathrm{mV})^{c}$ & $-30.3 \pm 1.0$ & $-28.2 \pm 0.8$ & $-0.3 \pm 2.3$ & $-15.3 \pm 2.3$ & $-9.6 \pm 2.3$ & $-15.5 \pm 2.3$ \\
\hline
\end{tabular}

a 3-sn-phosphatidylcholin egg lecithin.

${ }^{b}$ Lipoid E PC.

${ }^{c}$ Mean $\pm \mathrm{SD}, \mathrm{n}=3$. 
bility (Zetasizer 3 equipped with electrophoretic cell AZ-55, Malvern Instruments, Worchester, UK) (Table I). All emulsions were isoosmolar and had a $\mathrm{pH}$ within the range of 7-8.

\section{Cell Culture}

Cultured human mammary gland carcinoma cells, MCF7, were rinsed with PBS, trypsinized for 2-3 min, resuspended in Optimem 1 supplemented with 10\% FBS, $90 \mathrm{U} / \mathrm{ml}$ penicillin, and $90 \mu \mathrm{g} / \mathrm{ml}$ streptomycin. Then, $200 \mu \mathrm{l}$ of a cell suspension with 10,000 cells $/ \mathrm{ml}$ were seeded in each well of a 96 -well plate. Passages $188-196$ were cultivated at $37^{\circ} \mathrm{C}$ in a humidified atmosphere of $5 \% \mathrm{CO}_{2}$ until $90-100 \%$ confluency (6 days) before use. The medium was exchanged on the day before the experiment.

\section{Dehydrogenase Activity Assay (MTS/PMS assay)}

As an indirect measure of cytotoxicity, decrease in dehydrogenase activity was measured. In this test, $180 \mu \mathrm{l}$ of medium was removed from each well and replaced by $200 \mu \mathrm{l}$ of test solution. The test solutions consisted of $20 \mu \mathrm{l}$ of a 10 $\mathrm{mg} / \mathrm{ml}$ stock solution of ALA in RPMI or in emulsion mixed with $180 \mu \mathrm{l}$ RPMI (pH 5.7, 6.6, or 7.4) immediately before use. For all experiments, the $\mathrm{pH}$ of the $10 \mathrm{mg} / \mathrm{ml}$ stock solution was adjusted to 5.5 for stability reasons. The concentration of ALA was $1 \mathrm{mg} / \mathrm{ml}$ and the final $\mathrm{pH}$ in the test solutions corresponded to the $\mathrm{pH}$ of the buffer, that is, 5.7, 6.6, or 7.4.

The cells were protected from light by aluminum foil and incubated at $37^{\circ} \mathrm{C}$ in a humidified atmosphere of $5 \% \mathrm{CO}_{2}$ for $4 \mathrm{~h}$. The test solutions were removed, and the wells rinsed with $3 \times 300 \mu \mathrm{l} \mathrm{HBSS}$ of $37^{\circ} \mathrm{C}$. Then, $125 \mu \mathrm{l} \mathrm{MTS/PMS} \mathrm{re-}$ agent mixture diluted in HBSS $(240 \mu \mathrm{g} / \mathrm{ml}$ MTS and $2.4 \mu \mathrm{g} / \mathrm{ml}$ PMS) (24) were added, followed by incubation at $37^{\circ} \mathrm{C}$ under shaking $(50 \mathrm{rpm})$ for $1 \mathrm{~h}$. The absorbance was read at $492 \mathrm{~nm}$

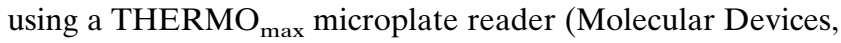
Sunnyvale, CA, USA).

The cytotoxicity of ALA in RPMI was examined for a concentration range of $1 \mu \mathrm{g} / \mathrm{ml}$ to $50 \mathrm{mg} / \mathrm{ml}(\mathrm{n}=8)$. The $\mathrm{o} / \mathrm{w}$ emulsions with or without $1 \mathrm{mg} / \mathrm{ml}$ ALA were used at a concentration of $10 \%(\mathrm{v} / \mathrm{v})$ in RPMI $(\mathrm{n}=8)$. For endocytosis inhibition, D-mannitol and $\mathrm{NH}_{4} \mathrm{Cl}$ were tested in a concentration range of $10 \mu \mathrm{M}$ to $1 \mathrm{M}$; monensin in the range of $0.1 \mu \mathrm{M}$ to $5 \mathrm{mM}$; brefeldin $\mathrm{A}$ in the range of 0.036 to $3.6 \mu \mathrm{M}$; and cytochalasin D between $0.011 \mu \mathrm{M}$ and $1.1 \mathrm{mM}$. These tests were all done with and without $1 \mathrm{mg} / \mathrm{ml} \mathrm{ALA}(\mathrm{n}=4)$.

In each experiment, RPMI was used as negative control and $2 \%(\mathrm{v} / \mathrm{v})$ Triton X-100 in RPMI as positive control. As a blind reference, the assays were performed without cells.

\section{Uptake of ALA and Metabolism to PpIX}

For all cell experiments, ALA was added from freshly prepared stock solutions or emulsions which contained 10 $\mathrm{mg} / \mathrm{ml}$ of ALA and had a $\mathrm{pH}$-value adjusted to 5.5 for stability reasons. In the test solutions, the ALA preparations were generally diluted in the appropriate buffer to a concentration of $1 \mathrm{mg} / \mathrm{ml}$ and the emulsion generally to $10 \%(\mathrm{v} / \mathrm{v})$. The $\mathrm{pH}$ was adjusted to the desired value for the experiment.

\section{Effect of the $p H$ Value of the Incubation Medium}

Initially, $180 \mu \mathrm{l}$ of the medium was removed and replaced by $180 \mu \mathrm{l}$ of RPMI (pH-adjusted to $5.7,6.6$, or 7.4 ), or
$20 \mu \mathrm{l}$ of the o/w emulsions without ALA was mixed with 160 $\mu \mathrm{l}$ of $\mathrm{pH}$-adjusted RPMI and added to the cells. Then, $20 \mu \mathrm{l}$ of a stock solution of ALA in RPMI was added to each well. Before each reading, mixing was done for $2 \mathrm{~s}$ in the fluorescence plate reader (FluoroCount plate reader, Packard Instrument, Meriden, CT, USA). The settings ( $\lambda$ excitation: 400 nm; $\lambda$ emission: $620 \mathrm{~nm}$; PMT: $1100 \mathrm{~V}$; gain: 12 ) were kept for all readings. The standard curve of PpIX was linear up to 400 $\mathrm{nM}$. The final $\mathrm{pH}$ value of the test mixture (ALA stock solution in RPMI) was comparable to the initial value of the RPMI, that is, 5.7-5.8, 6.6-6.7, and 7.4 for the experiments referred to as $\mathrm{pH} 5.7,6.6$, and 7.4, respectively. The cells were protected from light with aluminum foil and incubated for up to $4 \mathrm{~h}$. Readings of PpIX fluorescence were taken after 0 and $30 \mathrm{~min}$ as well as after 1, 2, 3, and $4 \mathrm{~h}$. After $4 \mathrm{~h}$, the viability of the cells was examined by rinsing carefully with $3 \times 300 \mu l$ HBSS of $37^{\circ} \mathrm{C}$, and adding MTS/PMS reagent mixture to each well. The number of repetitions was 8 .

\section{Effect of Emulsion Concentration}

At $\mathrm{pH} 5.7$ and 7.4, the concentration of LV20 and SOPS $(0.2)$ in the incubation medium was increased 2 and 3 times, respectively, keeping the total volume in each well constant at $220 \mu$ l. Further, LV20 and SOPS(0.2) were mixed in equal volumes of $10 \mu \mathrm{l}$ or $20 \mu \mathrm{l}$ each and tested. The experiment was carried out as described as described in "Effect of the $\mathrm{pH}$ Value of the Incubation Medium," above.

\section{Effect of Temperature and Duration of Preincubation}

The cells were kept in RPMI at either $4^{\circ} \mathrm{C}$ or $37^{\circ} \mathrm{C}$ for 30 min or $2 \mathrm{~h}$. The test formulations $(20 \mu \mathrm{l})$, with or without 1.0 $\mathrm{mg} / \mathrm{ml}$ ALA, were mixed with $200 \mu \mathrm{l}$ of RPMI and applied to the cells. The cells were then washed with ice-cold HBSS $(3 \times$ $300 \mu \mathrm{l}), 220 \mu \mathrm{l}$ RPMI was added, and incubation was continued at $37^{\circ} \mathrm{C}$ for $4 \mathrm{~h}$, regardless of whether the cells had previously been incubated at $4^{\circ} \mathrm{C}$ or $37^{\circ} \mathrm{C}$. As a control, MCF-7 cells were incubated at $37^{\circ} \mathrm{C}$ for $30 \mathrm{~min}$ or $2 \mathrm{~h}$ with ALA-free formulations after which ALA in RPMI $(1 \mathrm{mg} / \mathrm{ml})$ was added, and the fluorescence was then measured over $4 \mathrm{~h}$. Throughout the experiments, protection from light was maintained, and the fluorescence was measured every hour. The final $\mathrm{pH}$ of the test mixtures was 7.2-7.5. At the end of the experiment, the test mixtures were removed, and the MTS/PMS assay for cell viability was performed.

\section{Effect of ALA Concentration}

The formation of PpIX after administration of 0-1.0 $\mathrm{mg} / \mathrm{ml}$ ALA in RPMI at pH 5.7 and $\mathrm{pH} 7.4$ was evaluated. Identical ALA concentrations were also applied in the presence of LV20 and SOPS(0.2). The experiment was carried out as described in "Effect of the $\mathrm{pH}$ Value of the Incubation Medium," above.

The protein content per well was determined after lysis of cells treated with RPMI $(n=16)$. Cell lysis was achieved with $100 \mu \mathrm{l} 0.1 \%$ Triton ${ }^{\circledR} \mathrm{X}-100$ in HBSS for $4 \mathrm{~h}$, and the amount of protein was assessed by a BCA assay (25).

\section{Effect of Endocytosis Inhibitors}

The endocytosis inhibitor $\mathrm{NH}_{4} \mathrm{Cl}$ was added to the RPMI in concentrations of 20 and $50 \mathrm{mM}$. Monensin was used at a 
concentration of $50 \mu \mathrm{M}$, cytochalasin D at a concentration of $4.9 \mu \mathrm{M}$, and brefeldin $\mathrm{A}$ at a concentration of $8.9 \mu \mathrm{M}$. Incubation at $37^{\circ} \mathrm{C}$ for 30 min with the inhibitors in RPMI was done before the test formulation and ALA were added. Otherwise, the experiment was carried out described in "Effect of the $\mathrm{pH}$ Value of the Incubation Medium," above.

\section{Data Analysis}

The PpIX standard solution $(1 \mu \mathrm{M})$ in the 96 -well plate was scanned using a CARY Eclipse fluorescence spectrophotometer (Varian, Zug, Switzerland). At an excitation wavelength of $400 \mathrm{~nm}$, an emission maximum of $610 \mathrm{~nm}$ was observed.

The data was corrected for background (ALA-free test mixture applied to cells) and normalized relative to the first measurement $(\mathrm{t}=0)$. and $\mathrm{k}_{\mathrm{m}}$ :

For kinetic fitting, Eq. 1 was used to estimate $\mathrm{V}_{\max }$

$$
\frac{\mathrm{d}(\mathrm{PpIX})}{\mathrm{dt}}=\frac{\mathrm{V}_{\max } \times \mathrm{C}_{\mathrm{ALA}}}{\mathrm{k}_{\mathrm{m}}+\mathrm{C}_{\mathrm{ALA}}}
$$

ANOVA was used to evaluate differences, which were considered statistically significant if $\mathrm{p}<0.05$.

\section{RESULTS}

\section{Dehydrogenase Activity}

Dehydrogenase activity of MCF-7 cells exposed to up to $5 \mathrm{mg} / \mathrm{ml}$ ALA in RPMI at pH $7.4(97 \pm 21 \%)$ was not decreased relative to the control $(100 \pm 21 \%)$, whereas exposure to $10 \mathrm{mg} / \mathrm{ml}$ ALA was significantly more cytotoxic $(57 \pm 7 \%)$ $(\mathrm{p}<0.001)$. In general, dehydrogenase activity in the cells was the same at $\mathrm{pH} 7.4$ and 6.6, but decreased to approximately $60 \%$ when the $\mathrm{pH}$ of the incubation medium was changed to 5.7. For all the examined $\mathrm{pH}$ values, however, none of the ALA-containing test solutions showed differences from the RPMI, which had been adjusted to the same $\mathrm{pH}$ value, even when higher emulsion concentrations were used indicating that a decrease in enzyme activity was only due to changes in the $\mathrm{pH}$-value and not to the formulation.

The endocytosis inhibitors D-mannitol and $\mathrm{NH}_{4} \mathrm{Cl}$ were not cytotoxic at concentrations up to $100 \mathrm{mM}$ in RPMI of $\mathrm{pH}$ 7.4 (between $90 \pm 7 \%$ and $103 \pm 11 \%$ ), and the concomitant presence of $1 \mathrm{mg} / \mathrm{ml}$ ALA exerted no influence $(\mathrm{p}>0.05)$. Monensin up to $500 \mu \mathrm{M}(120 \pm 23 \%)$ and $50 \mu \mathrm{M}$ cytochalasin D $(93 \pm 13 \%)$ could also be used without any measurable toxic effects. Brefeldin A did not decrease the cell viability at
$3.6 \mu \mathrm{M}(116 \pm 22 \%)$, but did so at $17.8 \mu \mathrm{M}(20 \pm 15 \%)(\mathrm{p}<$ $0.001)$.

\section{Uptake of ALA and Metabolism to PpIX}

\section{Effect of the pH Value of the Incubation Medium}

When the $\mathrm{pH}$ of the final test formulation applied to the cells was increased from $\mathrm{pH} 5.7$ to 7.4, the amount of PpIX formed increased significantly (Fig. 1). Compared to the RPMI-control, the o/w emulsion enhanced the PpIX formation during the first hour of incubation. However, this difference became less important with increasing $\mathrm{pH}$ and with longer exposure time. After $4 \mathrm{~h}$ incubation, the amount of PpIX in the control cells was mostly comparable to that of the cells exposed to the o/w-emulsions.

\section{Effect of Emulsion Concentration}

The amount of PpIX formed upon an increase in the concentration of LV20 and SOPS(0.2) in RPMI at pH 7.4, in the presence of $1 \mathrm{mg} / \mathrm{ml}$ ALA, is shown in Fig. 2. At a 3 times higher LV20-concentration, the amount of PpIX observed after 1 and $4 \mathrm{~h}$ appeared to be higher. On the contrary, increasing amounts of SOPS(0.2) emulsion did not result in more PpIX. In RPMI at pH 5.7, the amount of PpIX was not increased when the concentration of LV20 and SOPS(0.2) was increased. Mixing of LV20 and SOPS(0.2) resulted in a decrease in the amount of PpIX (approximately $44 \mathrm{nM}$ PpIX), as compared to LV20 alone (52 $\pm 3 \mathrm{nM} \mathrm{PpIX),} \mathrm{and} \mathrm{to}$ a decrease as compared to $\operatorname{SOPS}(0.2)$ alone $(26 \pm 6 \mathrm{nM}$ PpIX).

\section{Effects of Temperature and Duration of Preincubation}

ALA metabolism to PpIX was examined over $4 \mathrm{~h}$ after the cells were preincubated with $1 \mathrm{mg} / \mathrm{ml}$ ALA in different formulations for $30 \mathrm{~min}$ or $2 \mathrm{~h}$, which was subsequently rinsed off. When preincubation was conducted at $4{ }^{\circ} \mathrm{C}$, no uptake of ALA occurred as no PpIX formed during the subsequent incubation for 1 and $4 \mathrm{~h}$ in ALA-free RPMI at $37^{\circ} \mathrm{C}$. Fig. 3 depicts the result after $2 \mathrm{~h}$ preincubation. However, the amount of PpIX seemed to be independent of the time of preincubation. Preincubation at $37^{\circ} \mathrm{C}$ resulted in kinetic profiles that were all quite similar suggesting that the uptake of ALA during the pre-incubation was comparable for the RPMI and emulsion formulations.

Similarly, when the cells were preincubated for $30 \mathrm{~min}$ or $2 \mathrm{~h}$ with ALA-free formulations, and the formulations were
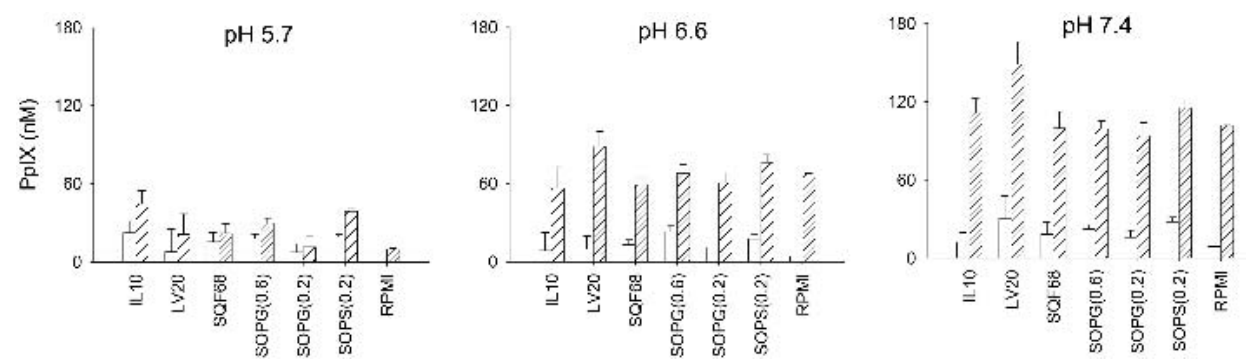

Fig. 1. Production of PpIX in MCF-7 cells during incubation at $37^{\circ} \mathrm{C}$ for $1 \mathrm{~h}(\square)$ and $4 \mathrm{~h}(\square)$ with 1 $\mathrm{mg} / \mathrm{ml}$ ALA formulations. The formulations (see Table I) were adjusted to $\mathrm{pH}$ values of 5.7, 6.6, and 7.4 immediately before addition to the cells. Mean \pm SD $(n=8)$. 

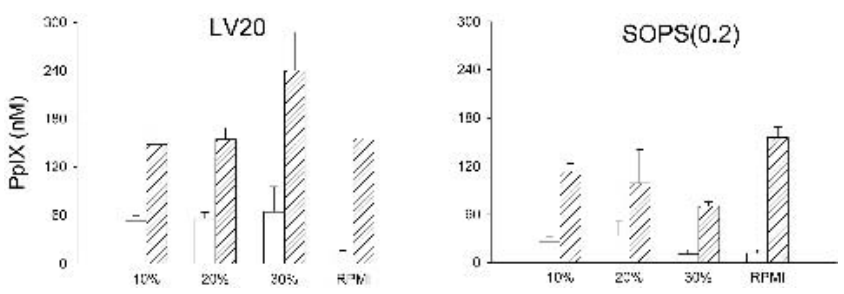

Fig. 2. Production of PpIX in MCF-7 cells during incubation at $37^{\circ} \mathrm{C}$ for $1 \mathrm{~h}(\square)$ and $4 \mathrm{~h}(\square)$ with $1 \mathrm{mg} / \mathrm{ml}$ ALA in LV20 and SOPS(0.2). Here, different concentrations of LV20 or SOPS(0.2) emulsions were used in the medium at $\mathrm{pH} 7.4$, with $10 \%$ being the standard concentration used. Mean $\pm \mathrm{SD}(\mathrm{n}=8)$.

then rinsed off, and the cells finally incubated with ALA in RPMI, no significant effect of the pre-incubation modality was observed on the ALA uptake and metabolism over $4 \mathrm{~h}$. For the other formulations, the same tendency was noted. No cytotoxicity was observed with any of the treatments.

\section{Effect of ALA Concentration}

The saturation profiles for the PpIX-formation upon incubation for $1 \mathrm{~h}$ and $4 \mathrm{~h}$ with ALA in RPMI of $\mathrm{pH} 5.7$ and 7.4, with and without LV20 and SOPS(0.2), are depicted in Fig. 4. The process of PpIX formation seems to be saturated when 1 $\mathrm{mg} / \mathrm{ml}$ ALA is applied to the cells, regardless of the test formulation used. The estimated $\mathrm{k}_{\mathrm{m}}$ and $\mathrm{V}_{\text {max }}$ values are compiled in Table II.

After $1 \mathrm{~h}$ of incubation $\mathrm{V}_{\max }$ is approximately 10 times higher in RPMI of $\mathrm{pH} 7.4$ than in RPMI of $\mathrm{pH}$ 5.7. Interestingly, $\mathrm{V}_{\text {max }}$ and $\mathrm{k}_{\mathrm{m}}$ values seemed to be unaffected by $\mathrm{pH}$ (7.4 or 5.7) when ALA was applied in $\operatorname{LV} 20$ or $\operatorname{SOPS}(0.2)$, but both increased when ALA was applied in RPMI. Furthermore, $\mathrm{V}_{\max }$ was approximately 2-4 times and 20-40 times higher for the emulsions than for RPMI at $\mathrm{pH} 7.4$ and 5.7, respectively. Statistical analysis of the data points after $1 \mathrm{~h}$ at ALA concentrations of $0.1,0.5$ and $1 \mathrm{mg} / \mathrm{ml}$ revealed a significantly higher PpIX formation in RPMI at pH 7.4 than at pH $5.4(\mathrm{p}<0.001)$. Very interestingly, at ALA concentrations of $0.5 \mathrm{mg} / \mathrm{ml}(\mathrm{p}<0.01)$ and $1 \mathrm{mg} / \mathrm{ml}(\mathrm{p}<0.001)$, the PpIX

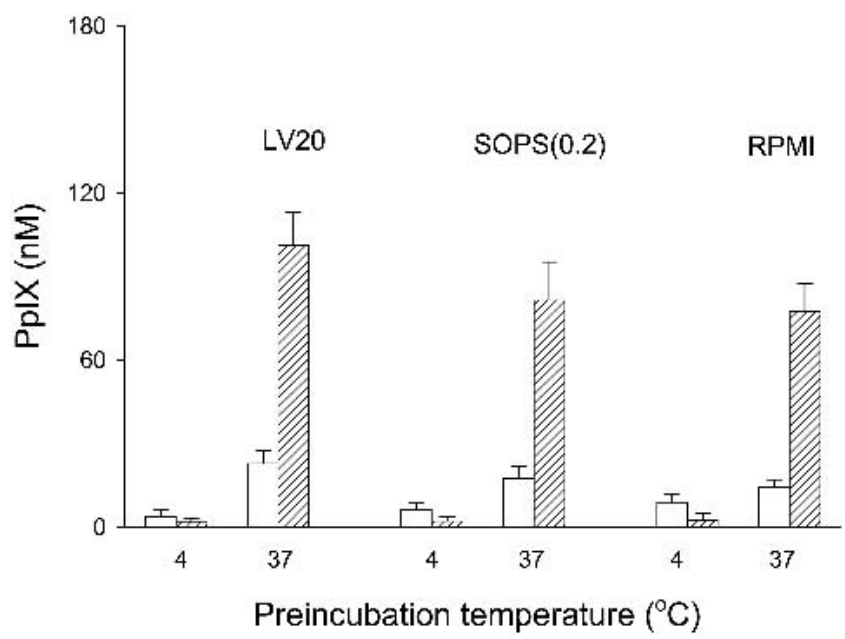

Fig. 3. Production of PpIX in MCF-7 cells during incubation at $37^{\circ} \mathrm{C}$ for $1 \mathrm{~h}(\square)$ and $4 \mathrm{~h}(\square)$ with ALA-free RPMI (pH 7.4), after preincubation for $2 \mathrm{~h}$ with $1 \mathrm{mg} / \mathrm{ml}$ ALA in LV20 or SOPS(0.2) emulsion or RPMI at $4^{\circ} \mathrm{C}$ or $37^{\circ} \mathrm{C}(\mathrm{pH} 7.4)$. Mean $\pm \mathrm{SD}(\mathrm{n}=8)$.
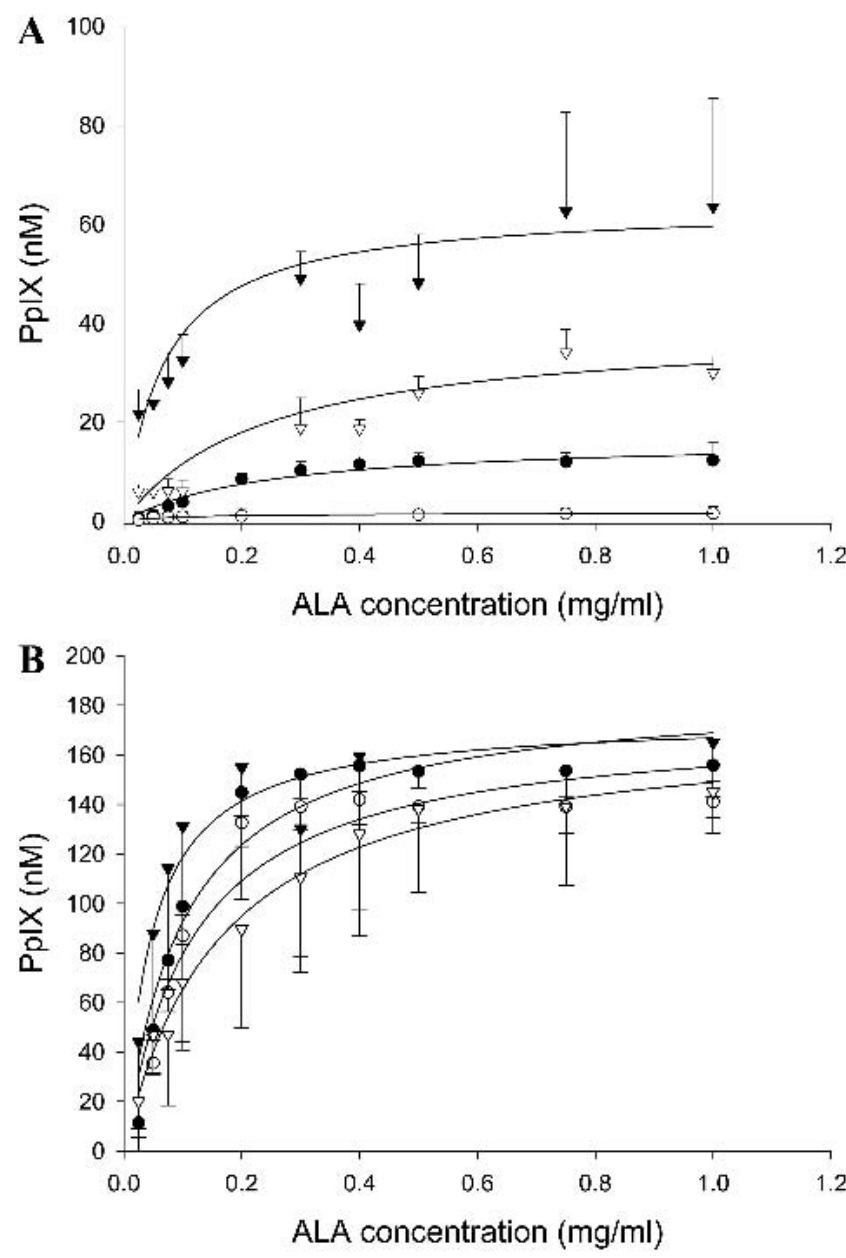

Fig. 4. PpIX production in MCF-7 cells after incubation at $37^{\circ} \mathrm{C}$ for $1 \mathrm{~h} \mathrm{(A)}$ and for $4 \mathrm{~h}(\mathrm{~B})$ with variable ALA concentrations in different emulsions and RPMI at pH 7.4 or 5.7. RPMI, pH 5.7 (O), RPMI, pH $7.4(\bullet), \operatorname{SOPS}(0.2), \mathrm{pH} 7.4(\nabla), \mathrm{LV} 20, \mathrm{pH} 7.4(\boldsymbol{\nabla})$. Mean values and $\mathrm{SD}$ are presented $(\mathrm{n}=8)$ and profiles fitted according to Eq. 1.

formation was higher with LV20 or SOPS(0.2) than with RPMI at $\mathrm{pH}$ 7.4. For the results obtained after $4 \mathrm{~h}$, the $\mathrm{V}_{\max }$ in RPMI at $\mathrm{pH} 7.4$ was comparable to RPMI at $\mathrm{pH} 5.7$ and to $\mathrm{V}_{\max }$ in either of the emulsions. At pH 5.7, however, the PpIX production seemed to reach a lower maximum when ALA was applied in emulsion. For both $1 \mathrm{~h}$ and $4 \mathrm{~h}$ results, the different formulations did not give substantial differences in the $\mathrm{k}_{\mathrm{m}}$ values even though there was a tendency toward lower $\mathrm{k}_{\mathrm{m}}$ values for the LV20 emulsion. However, it should be mentioned that with LV20, the fitting parameter is not optimal.

\section{Effect of Endocytosis Inhibitors}

The presence of PpIX found in MCF-7 cells exposed to ALA formulations and different endocytosis inhibitors is presented in Fig. 5. Some of the inhibitors decreased the amount of PpIX formed in the control cells $(17 \pm 2 \mathrm{nM} / \mathrm{h})$ exposed to RPMI, that is, $\left.50 \mathrm{mM} \mathrm{NH} \mathrm{ml}_{4} \mathrm{Cl}<0.001\right)$, monensin $(\mathrm{p}<$ $0.001)$, and brefeldin A $(\mathrm{p}<0.05)$. Cytochalasin D seemed to increase the intracellular amount of PpIX as compared to control cells $(23 \pm 6 \mathrm{nM} / \mathrm{h})(\mathrm{p}<0.05)$ and to cause no change in the effect of the $\mathrm{o} / \mathrm{w}$-emulsions. 
Table II. $\mathrm{V}_{\max }$ and $\mathrm{k}_{\mathrm{m}}$ Values for Production of PpIX in MCF-7 Cells after Incubation for $1 \mathrm{~h}$ and $4 \mathrm{~h}$ in RPMI or Emulsion at pH 5.7 or $7.4^{a}$

\begin{tabular}{|c|c|c|c|c|c|c|c|}
\hline \multirow[b]{2}{*}{$\begin{array}{l}\text { ALA } \\
\text { formulation }\end{array}$} & \multirow[b]{2}{*}{$\begin{array}{l}\mathrm{pH} \text { of incubation } \\
\text { medium }\end{array}$} & \multicolumn{3}{|c|}{$1 \mathrm{~h}$} & \multicolumn{3}{|c|}{$4 \mathrm{~h}$} \\
\hline & & $\begin{array}{c}\mathrm{k}_{\mathrm{m}} \\
(\mathrm{mg} / \mathrm{ml})\end{array}$ & $\begin{array}{l}\mathrm{V}_{\max } \\
(\mathrm{nM})^{b}\end{array}$ & $\mathrm{R}^{2}$ & $\begin{array}{c}\mathrm{k}_{\mathrm{m}} \\
(\mathrm{mg} / \mathrm{ml})\end{array}$ & $\begin{array}{l}\mathrm{V}_{\max } \\
(\mathrm{nM})^{b}\end{array}$ & $\mathrm{R}^{2}$ \\
\hline RPMI & 5.7 & $0.10 \pm 0.02$ & $1.66 \pm 0.09$ & 0.9647 & $0.12 \pm 0.04$ & $173.53 \pm 16.54$ & 0.8981 \\
\hline LV20 & 5.7 & $0.09 \pm 0.06$ & $65.70 \pm 11.73$ & 0.5111 & $0.06 \pm 0.04$ & $74.35 \pm 13.50$ & 0.5683 \\
\hline SOPS(0.2) & 5.7 & $0.17 \pm 0.08$ & $39.32 \pm 6.53$ & 0.7102 & $0.09 \pm 0.04$ & $67.97 \pm 8.95$ & 0.8056 \\
\hline RPMI & 7.4 & $0.25 \pm 0.07$ & $16.80 \pm 1.80$ & 0.9478 & $0.10 \pm 0.02$ & $185.92 \pm 12.70$ & 0.9285 \\
\hline LV20 & 7.4 & $0.07 \pm 0.02$ & $63.64 \pm 5.53$ & 0.7718 & $0.05 \pm 0.02$ & $176.20 \pm 15.52$ & 0.8881 \\
\hline $\operatorname{SOPS}(0.2)$ & 7.4 & $0.24 \pm 0.09$ & $39.44 \pm 5.55$ & 0.8910 & $0.17 \pm 0.02$ & $173.60 \pm 6.33$ & 0.9865 \\
\hline
\end{tabular}

${ }^{a}$ Fitting according to Eq. 1 . Mean $\pm \mathrm{SD}(\mathrm{n}=8)$.

${ }^{b}$ The amount of protein per well was $1.82 \pm 0.09 \mathrm{mg} /$ well $(\mathrm{n}=16)$.

Therefore, only the effect of $20 \mathrm{mM} \mathrm{NH}_{4} \mathrm{Cl}$ and 20 and 50 $\mathrm{mM}$ D-mannitol was considered for PpIX production after incubation with the o/w emulsions. The PpIX formation was significantly decreased when the cells were incubated with ALA in SOPG(0.6), SOPG(0.2), and SOPS(0.2) in the presence of $20 \mathrm{mM}$ or $50 \mathrm{mM}$ D-mannitol $(\mathrm{p}<0.01)$, or of $20 \mathrm{mM}$ $\mathrm{NH}_{4} \mathrm{Cl}(\mathrm{p}<0.05)$. Conversely, $\mathrm{NH}_{4} \mathrm{Cl}$ and D-mannitol did not appear to affect the PpIX formation significantly when ALA was applied to the cells with less negatively charged emulsion droplets, that is, IL10, LV20 and SQF68, even though a slight tendency toward reduced PpIX formation was noticed for IL10 and SQF68 in the presence of $50 \mathrm{mM}$ D-mannitol.

\section{DISCUSSION}

\section{Uptake of ALA and Metabolism to PpIX}

\section{Effect of pH, Time, Temperature, and Concentration}

The PpIX formation in cells exposed to ALA at $\mathrm{pH} 5.7$ was generally higher when applied in the buffered emulsions than in the buffer solution (Fig. 1). This could indicate that the emulsions favored the extracellular stability or intracellu-

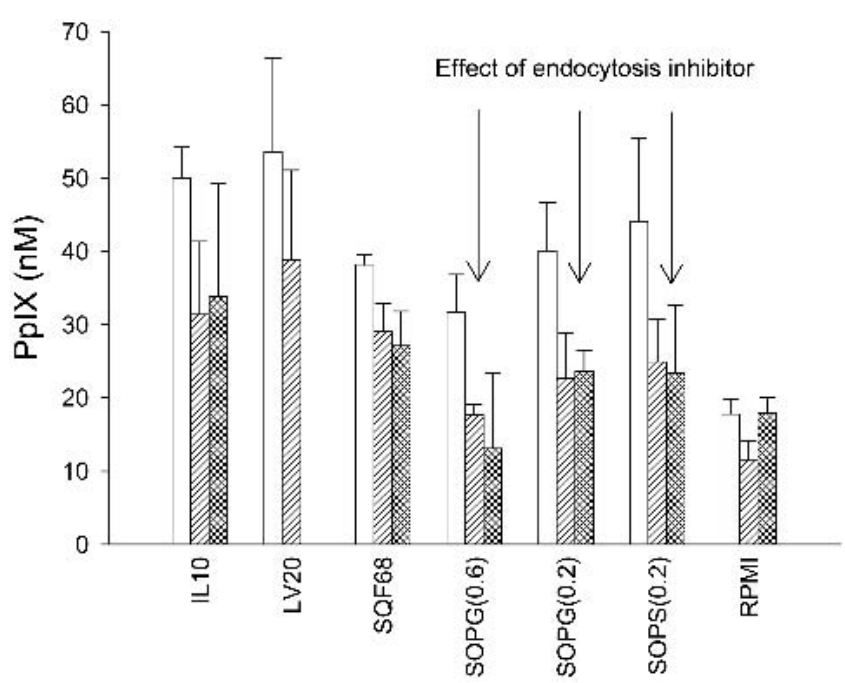

Fig. 5. Inhibition of PpIX production in MCF-7 cells after incubation at $37^{\circ} \mathrm{C}$ for $1 \mathrm{~h}$ with $1 \mathrm{mg} / \mathrm{ml}$ ALA in emulsion or RPMI, pH 7.4. No inhibitor $(\square), 20 \mathrm{mM} \mathrm{NH}_{4} \mathrm{Cl}(\square), 50 \mathrm{mM}$ mannitol $(\square)$. Mean + $\mathrm{SD}(\mathrm{n}=8)$. lar metabolism of ALA at this $\mathrm{pH}$. However, in previous studies, o/w emulsions (including IL10 and LV20) did not increase the stability of ALA significantly as compared to a buffer solution (4). Furthermore, the 3- to 4-fold increase in the PpIX formation at $\mathrm{pH} 7.4$ compared to $\mathrm{pH} 5.7$ was similar regardless of whether ALA was applied in $\mathrm{o} / \mathrm{w}$ emulsions or in buffer. This indicates that the effect of $\mathrm{pH}$ appears to be certainly important for metabolism although the importance for uptake should not be excluded. The optimal $\mathrm{pH}$ of 7.4 for incubation correlates well with the fact that the metabolic cascade from ALA to PpIX occurs in the mitochondria (9).

The amount of PpIX formed in the MCF-7 cells increased with longer exposure time to ALA. This could be due to both increased uptake and increased intracellular metabolism. The lack of intracellular PpIX formation at $4^{\circ} \mathrm{C}$ could simply be the result of a diminished metabolic activity of the cells. It has been shown that low temperature hinders PpIX production, but not the penetration of ALA into mouse and human skin (26). However, since no PpIX was formed in the cells incubated at $37^{\circ} \mathrm{C}$ for up to $4 \mathrm{~h}$ following pre-incubation with ALA for up to $2 \mathrm{~h}$ at $4^{\circ} \mathrm{C}$, cellular uptake of ALA also appears to depend on temperature, which supports an uptake mechanism by transporter(s) or endocytosis. In accordance with previous findings, the intracellular accumulation of PpIX upon application of ALA occurs by saturable kinetics (7), with saturation manifesting in the concentration range of $0-1$ $\mathrm{mg} / \mathrm{ml}$ (Fig. 4). The conversion from extracellular ALA to intracellular PpIX is probably best described by a twocompartment model with Michaelis-Menten kinetics (27). It has previously been shown that the affinity of ALA for the receptor $\left(\mathrm{k}_{\mathrm{m}}\right)$ is not altered by changes in the extracellular $\mathrm{pH}$, whereas the maximal transport rate $\left(\mathrm{V}_{\max }\right)$ is (15). A comparable observation derives from the present study, when ALA was applied in buffer. However, when o/w emulsions were used, $V_{\max }$ seemed to remain unaffected by a change in $\mathrm{pH}$. This difference in the maximum amount of PpIX formed when applying the LV20 or the SOPS $(0.2)$ emulsion for $1 \mathrm{~h}$, as compared to buffer, could be due to either changes in the uptake mechanism or effects of emulsion components on the metabolism in terms of inducing or inhibiting certain enzymes of the heme synthesis pathway, or else effects of emulsion components on the rate of distribution to the mitochondria. The latter two mechanisms require that the cells ingest emulsion components, a phenomenon which deserves further investigations. Because $\mathrm{V}_{\max }$ after $4 \mathrm{~h}$ in RPMI at $\mathrm{pH} 5.7$ is 
comparable to that after $4 \mathrm{~h}$ in RPMI at $\mathrm{pH} 7.4$, it seems that during the first hour of incubation, the uptake of ALA is the rate-limiting step. The fact that the PpIX formation upon 4-h exposure to the emulsions is lower at $\mathrm{pH} 5.7$ compared to $\mathrm{pH}$ 7.4 suggests that the emulsions limit the long-term accumulation of PpIX at low pH. Interestingly, this difference is not observed at $\mathrm{pH} 7.4$, suggesting a different mechanism of action for the emulsions at different $\mathrm{pH}$ values.

In general, the effects of $\mathrm{pH}$, time, temperature and concentration observed in this study reflect a saturable uptake of ALA and future examination of the presence of specific transporters in the MCF-7 cell line is, therefore, of interest. Both the PEPT2 and BETA transporters have been suggested to transport ALA There is strong evidence for the presence of the PEPT2 transporter in mammary gland epithelium (15). Contrastingly, the BETA transporter, but not the PEPT2 transporter (16) has been identified in a mammary epithelial cell line $(19,20)$.

\section{Effect of $\mathrm{O} / \mathrm{W}$ Emulsion}

The accumulation of PpIX in MCF-7 cells was increased when the amphoteric ALA was formulated in certain o/wemulsions-especially LV20 and SOPS(0.2) (Fig. 1). Previously, an o/w nanoemulsion has been shown to increase the cellular fluorescence very slightly after uptake of another photosensitizer, mTHPC (meta-tetra(hydroxypropyl)chlorine), in macrophage-like cells (J774), but to decrease the uptake of the $m$ THPC in HT29 adenocarcinoma cell line (28). DMSO in an o/w-emulsion has been demonstrated to improve the permeation of ALA across mouse skin in vitro (29) and in vivo (14) and also with increased PpIX synthesis (14).

The mechanisms responsible for the enhanced PpIX formation in the presence of emulsions could be explained by the present results. As ALA is an amphoteric molecule, it probably interacts strongly through ionic forces with the amphoteric lecithin used as emulsifier in most of the tested emulsions (Table I). An excess concentration of ALA at the o/w interface could have promoted the contact between ALA and the cell surface, resulting in an increased local concentration of ALA at the cell surface. Such locally increased ALA concentration at the epithelial surface could have favored cellular uptake of ALA, which probably occurred via endocytosis and not, as previously stated, by an increased affinity for (or velocity of) a transporter. In this context, it may be appropriate to consider the role of clathrin-coated pits in cellular plasma membranes. It has been shown that certain endogenous proteins/receptors become clustered in coated pits upon binding to soluble ligands (30), and that such clustering can result in an invagination to vesicles/endosomes, which are acidified. This hypothetic mechanism could explain the present results with some of the endocytosis inhibitors used, which decreased the amount of PpIX in the cells. Indeed, hyperosmolarity induced by mannitol as well as acidification of the cytoplasm induced by $\mathrm{NH}_{4} \mathrm{Cl}$ decreased the formation of $\mathrm{PpIX}$ in a concentration dependent manner (Fig. 5). This coincides with previous observations that endocytosis mediated by coated pits is inhibited by hyperosmolarity (by mannitol) and acidification of the cytoplasm (by $\mathrm{NH}_{4} \mathrm{Cl}$ ) (31), whereas endocytosis via non-coated pits is not inhibited by hyperosmolarity (32).

The oil droplets of the $\mathrm{o} / \mathrm{w}$-emulsions did not interact with the cell plasma membrane in a harmful way, since none of the emulsions induced any decrease in dehydrogenase activity. Furthermore, no effect on plasma membrane integrity was noticed, since 30 min pre-incubation with ALA-free test formulations followed by incubation with ALA formulations for up to $4 \mathrm{~h}$ did not alter the accumulation of PpIX as compared to pre-incubation with buffer (Fig. 3).

The type or charge of the phospholipid in the o/wemulsions seemed to be important to the amount of ALA endocytosed and PpIX formed, as LV20 yielded a higher $\mathrm{V}_{\text {max }}$ than SOPS(0.2) (Tables I and II). This is also supported by the data obtained from the inhibitor study (Fig. 5). Here, the IL10 and LV20 formulations produced higher amounts of PpIX than SOPG(0.6) and SOPG(0.2) in which up to $50 \%$ of the phosphatidylcholine/lecithin was replaced by the negatively charged phosphatidylglycerol. For the formulations which was added only $16 \%$ phosphatidylglycerol, SOPG(0.2), or $16 \%$ of negatively charged phosphatidylserine, $\operatorname{SOPS}(0.2)$, the difference in the amount of PpIX formed is less evident. Further support for the beneficial effect of the amphoteric phosphatidylcholine over the anionic phosphatidyl derivatives is provided by the increased PpIX formation with increasing concentrations of LV20 (10-30\%) in the incubation medium on one side and by the lowered PpIX production with increasing $\operatorname{SOPS}(0.2)$ concentrations on the other side (Fig. 2). Whether the zeta potential played a significant role remains uncertain. The negatively charged oil droplets in LV20 should be repelled by the plasma membrane more strongly, at least in theory, than the less negatively charged oil droplets of SOPS(0.2) (Table 1). Furthermore, the fact that the amount of PpIX formed at $\mathrm{pH} 7.4$ in the presence of ALA in the SQF68 formulation does not differ significantly from the SOPG and SOPS emulsions suggests that the type of oil, the droplet size and zeta potential play a minor role.

In conclusion, the present data show that the formation of PpIX in MCF-7 cells exposed to ALA depends on $\mathrm{pH}$ as well as time, temperature and concentration-both when ALA is applied in buffer and in o/w-formulations. By introducing ALA in an o/w-emulsion, it may be possible to use lower concentrations of ALA and shorten periods of incubation for accumulation of PpIX in epithelial cells in order to diagnose and treat superficial neoplastic cells. This could not only reduce the risk of side effects by the treatment, but also save time. The present results raise questions regarding the exact mechanisms involved and require further studies with organ cultures of normal cells and tumor cells or in vivo studies to ascertain tumor selectivity.

\section{ACKNOWLEDGMENTS}

The Alfred Benzon Foundation is acknowledged for the donation of a grant to Hanne Mørck Nielsen. ASAT AG $(\mathrm{CH}-\mathrm{Zug})$ and the Commission for Technology and Innovation (KTI grant no. 3804.1, CH-Bern) are acknowledged for financial support. We also thank Ruth Alder and Manuela Grüninger for excellent technical assistance and Hans P. Merkle (Institute of Pharmaceutical Sciences ETH Zürich) and Hans W. Schmid (ASAT AG) for helpful discussions.

\section{REFERENCES}

1. K. Lang, P. Lehmann, K. Bolsen, T. Ruzicka, and C. Fritsch. Aminolevulinic acid: pharmacological profile and clinical indication. Expert Opin. Investig. Drugs 10:1139-1156 (2001). 
2. E. L. Taylor and S. B. Brown. The advantages of aminolevulinic acid photodynamic therapy in dermatology. J. Dermatolog. Treat. 13(Suppl 1):S3-11 (2002).

3. R. M. Szeimies, M. Landthaler, and S. Karrer. Non-oncologic indications for ALA-PDT. J. Dermatolog. Treat. 13(Suppl 1):S13-S18 (2002).

4. A. Bunke, O. Zerbe, H. Schmid, G. Burmeister, H. P. Merkle, and B. Gander. Degradation mechanism and stability of 5-aminolevulinic acid. J. Pharm. Sci. 89:1335-1341 (2000).

5. B. Elfsson, I. Wallin, S. Eksborg, K. Rudaeus, A. M. Ros, and H. Ehrsson. Stability of 5-aminolevulinic acid in aqueous solution. Eur. J. Pharm. Sci. 7:87-91 (1999).

6. M. Novo, G. Huttmann, and H. Diddens. Chemical instability of 5 -aminolevulinic acid used in the fluorescence diagnosis of bladder tumours. J. Photochem. Photobiol. B 34:143-148 (1996).

7. A. Casas, C. Perotti, M. Saccoliti, P. Sacca, H. Fukuda, and A. M. Batlle. ALA and ALA hexyl ester in free and liposomal formulations for the photosensitisation of tumour organ cultures. $\mathrm{Br}$. J. Cancer 86:837-842 (2002).

8. Y. Ninomiya, Y. Itoh, S. Tajima, and A. Ishibashi. In vitro and in vivo expression of protoporphyrin IX induced by lipophilic 5-aminolevulinic acid derivatives. J. Dermatol. Sci. 27:114-120 (2001).

9. J. Morgan and A. R. Oseroff. Mitochondria-based photodynamic anti-cancer therapy. Adv. Drug Deliv. Rev. 49:71-86 (2001).

10. V. Vonarx, S. Eleouet, J. Carre, P. Ioss, A. Gouyette, A. M. Leray, C. Merle, Y. Lajat, and T. Patrice. Potential efficacy of a delta 5-aminolevulinic acid bioadhesive gel formulation for the photodynamic treatment of lesions of the gastrointestinal tract in mice. J. Pharm. Pharmacol. 49:652-656 (1997).

11. S. Lieb, R. M. Szeimies, and G. Lee. Self-adhesive thin films for topical delivery of 5-aminolevulinic acid. Eur. J. Pharm. Biopharm. 53:99-106 (2002).

12. A. F. Hurlimann, G. Hanggi, and R. G. Panizzon. Photodynamic therapy of superficial basal cell carcinomas using topical 5-aminolevulinic acid in a nanocolloid lotion. Dermatology 197:248254 (1998).

13. K. Svanberg, T. Andersson, D. Killander, I. Wang, U. Stenram, S. Andersson-Engels, R. Berg, J. Johansson, and S. Svanberg. Photodynamic therapy of non-melanoma malignant tumours of the skin using topical delta-amino levulinic acid sensitization and laser irradiation. Br. J. Dermatol. 130:743-751 (1994).

14. A. Casas, H. Fukuda, G. Di Venosa, and A. M. Batlle. The influence of the vehicle on the synthesis of porphyrins after topical application of 5-aminolaevulinic acid. Implications in cutaneous photodynamic sensitization. Br. J. Dermatol. 143:564-572 (2000).

15. F. Doring, J. Walter, J. Will, M. Focking, M. Boll, S. Amasheh, W. Clauss, and H. Daniel. Delta-aminolevulinic acid transport by intestinal and renal peptide transporters and its physiological and clinical implications. J. Clin. Invest. 101:2761-2767 (1998).

16. D.A. Groneberg, F. Doring, S. Theis, M. Nickolaus, A. Fischer, and H. Daniel. Peptide transport in the mammary gland: expression and distribution of PEPT2 mRNA and protein. Am. J. Physiol. Endocrinol. Metab. 282:E1172-E1179 (2002).

17. J. Neumann and M. Brandsch. Delta-aminolevulinic acid transport in cancer cells of the human extrahepatic biliary duct. $J$. Pharmacol. Exp. Ther. 305:219-224 (2003).

18. M. Irie, T. Terada, K. Sawada, H. Saito, and K. Inui. Recognition and transport characteristics of nonpeptidic compounds by basolateral peptide transporter in Caco-2 cells. J. Pharmacol. Exp. Ther. 298:711-717 (2001).

19. M. Bermudez-Moretti, S. Correa-Garcia, C. Perotti, A. Batlle, and A. Casas. Delta-Aminolevulinic acid transport in murine mammary adenocarcinoma cells is mediated by beta transporters. Br. J. Cancer 87:471-474 (2002).

20. S. Correa-Garcia, A. Casas, C. Perotti, A. Batlle, and M. Bermudez-Moretti. Mechanistic studies on delta-aminolevulinic acid uptake and efflux in a mammary adenocarcinoma cell line. $B r . J$. Cancer 89:173-177 (2003).

21. E. Rud, O. Gederaas, A. Hogset, and K. Berg. 5-aminolevulinic acid, but not 5-aminolevulinic acid esters, is transported into adenocarcinoma cells by system BETA transporters. Photochem. Photobiol. 71:640-647 (2000).

22. H. D. Soule, J. Vazguez, A. Long, S. Albert, and M. Brennan. A human cell line from a pleural effusion derived from a breast carcinoma. J. Natl. Cancer Inst. 51:1409-1416 (1973).

23. L. Wyld, M. Tomlinson, M. W. Reed, and N. J. Brown. Aminolaevulinic acid-induced photodynamic therapy: cellular responses to glucose starvation. Br. J. Cancer 86:1343-1347 (2002).

24. J. Jacobsen, M. Pedersen, and M. R. Rassing. TR146 cells as a model for human buccal epithelium: II. Optimisation and use of a cellular sensitivity MTS/PMS assay. Int. J. Pharm. 141:217-225 (1996).

25. H. U. Eirheim, C. Bundgaard, and H. M. Nielsen. Evaluation of different toxicity assays applied to proliferating cells and to stratified epithelium in relation to permeability enhancement with glycocholate. Toxicol. In Vitro 18:649-657 (2004).

26. J. Moan, K. Berg, O. B. Gadmar, V. Iani, L. Ma, and P. Juzenas. The temperature dependence of protoporphyrin IX production in cells and tissues. Photochem. Photobiol. 70:669-673 (1999).

27. M. C. Aalders, N. van der Vange, W. M. Star, and H. J. Sterenborg. A mathematical evaluation of dose-dependent PpIX fluorescence kinetics in vivo. Photochem. Photobiol. 74:311-317 (2001).

28. O. Bourdon, V. Mosqueira, P. Legrand, and J. Blais. A comparative study of the cellular uptake, localization and phototoxicity of meta-tetra(hydroxyphenyl) chlorin encapsulated in surfacemodified submicronic oil/water carriers in HT29 tumor cells. $J$. Photochem. Photobiol. B 55:164-171 (2000).

29. F. S. De Rosa, J. M. Marchetti, J. A. Thomazini, A. C. Tedesco, and M. V. Bentley. A vehicle for photodynamic therapy of skin cancer: influence of dimethylsulphoxide on 5-aminolevulinic acid in vitro cutaneous permeation and in vivo protoporphyrin IX accumulation determined by confocal microscopy. J. Control. Rel. 65:359-366 (2000).

30. S. L. Hussey and B. R. Peterson. Efficient delivery of streptavidin to mammalian cells: clathrin-mediated endocytosis regulated by a synthetic ligand. J. Am. Chem. Soc. 124:6265-6273 (2002).

31. J. S. Choi, K. R. Kim, D. W. Ahn, and Y. S. Park. Cadmium inhibits albumin endocytosis in opossum kidney epithelial cells. Toxicol. Appl. Pharmacol. 161:146-152 (1999).

32. C. A. Casey, R. L. Wiegert, and D. J. Tuma. Effect of hyperosmolarity on both receptor-mediated and fluid-phase endocytosis in ethanol-fed animals. Biochem. Pharmacol. 49:1117-1123 (1995). 